\title{
Environmentally responsible behaviour in outdoor recreation: the moderating impact of COVID-19 related risk perception
}

\author{
Nguyen Thi Khanh Chi
}

\begin{abstract}
Purpose - This study examines the mediating role of motivation on outdoor recreation on the attitude-behavior and social marketing-behavior linkages. The paper scrutinizes the moderating impact of coronavirus disease 2019 (COVID-19) risk perception in transforming individual motivation on nature-based outdoor recreation into environmentally responsible behavior.

Design/methodology/approach - Data were collected and conducted in Vietnamese National Parks. The dataset consists of 900 valid responses by domestic travelers. The research was operationalized using empirical data and employed structural equation modeling (SEM) and SPSS PROCESS analysis.

Findings - First, this study confirms that outdoor recreation activities and business's marketing on social networks tend to transform into support for individual behavior in terms of protecting environment and having responsibility for environment. Second, the current paper also represents the academic efforts to contribute to outdoor recreation literature by explaining the current global problem that has caused serious upheaval in global society as well as individual life. The findings not only confirmed the mediating role of nature-based outdoor recreation motivation between attitude and behavior, but also examined the moderating effect of COVID-19 risk perception in the relationship between motivation and behavior.

Originality/value - The findings indicate the significant association of social marketing, environment attitudes, outdoor recreation motivation and environmentally responsible behavior. The findings not only confirmed the mediating role of nature-based outdoor recreation motivation between attitude and behavior, but also examined the moderating effect of COVID-19 risk perception in the relationship between motivation and behavior. These results provide key insights about examining visitors' behavior for environment protection during future infectious disease outbreaks.
\end{abstract}

Keywords Outdoor recreation motivation, Social marketing, Environmental attitude, Environmentally responsible behavior

Paper type Research paper

\section{Introduction}

It has been widely observed that outdoor recreation is becoming increasingly popular in research (Margaryan and Fredman, 2017; Nordh et al., 2017; Komossa et al., 2020). However, naturebased activities, which are considered as a form of outdoor recreation, have recently attracted the increasing interest of both academics and practitioners (Melly and Hanrahan, 2020). The objective of developing nature-based outdoor recreation is to improve public health and environmental protection (Marasinghe et al., 2021; Høyem, 2020). Especially, outdoor recreation providers need to develop strategies to minimize the losses resulting from the impact of the coronavirus disease 2019 (COVID-19) pandemic in the future (Humagain and Singleton, 2021). Consequently, it is important to understand the impact of factors on the environmentally responsible behavior towards outdoor recreation in the context of the COVID-19 pandemic.
Nguyen Thi Khanh Chi is based at the Foreign Trade University, Hanoi, Vietnam.

Received 30 September 2021 Revised 28 November 2021

21 January 2022

26 January 2022

Accepted 27 January 2022

(C) Nguyen Thi Khanh Chi. Published in Journal of Tourism Futures. Published by Emerald Publishing Limited. This article is published under the Creative Commons Attribution (CC BY 4.0) licence. Anyone may reproduce, distribute, translate and create derivative works of this article (for both commercial and non-commercial purposes), subject to full attribution to the original publication and authors.

The full terms of this licence may be seen at http://

creativecommons.org/licences/ by/4.0/legalcode

This research is funded by Foreign Trade University under grant number FTURP02-202012. The author acknowledges the support and facilities from Foreign Trade University for this study. 
Since there has been an increase in public awareness of environmental problems (Rustam et al., 2020), research examining the relationship between environmental attitudes and behavior becomes more popular. Several scholars have supported the linkage between environmental attitude and environmentally responsible behavior (Liu et al., 2021; Gupta et al., 2021a). More recently, Kil et al. (2014) revealed a low-modest relationship through the transition of outdoor recreation motivation in the Florida National Scenic Trail of America. However, the previous results were mentioned and studied in developed countries (American and Western European). In developing countries, this outcome of indeterminate relationships among environmental attitude, outdoor recreation motivation and environmentally responsible behavior is still ambiguous (Pham and Chi, 2020). It is consequently needed to continuously contribute to the attitude-behavior for finding out relevant details and specific instances for a different context.

Another potential antecedent that so far has been neglected in the recreation literature is social marketing. Social marketing utilizes marketing concepts and tools to promote pro-social behavior (Gordon et al., 2018). Social marketing offers one line of inquiry (Truong and Hall, 2017) that may be applied in the tourism industry to move and motivate tourists to consider actions that can protect the planet, whilst still enabling travel. In the future, social marketing certainly becomes more important for organizations in their marketing campaigns and in targeting outdoor recreational users (Borden and Mahamane, 2020). Aspects of social marketing have targeted outdoor recreational users (i.e. skiers, boaters, birders, walkers, etc.), and Tkaczynski et al. (2020) have explained opportunities for non-profit organizations to utilize this tool. However, the role of social marketing in understanding environmentally responsible behavior in the context of the COVID-19 pandemic has not been clearly defined. Drawing on the work of Borden and Mahamane (2020), a meta-analysis of the impact of social marketing on outdoor recreational advocacy groups, the current paper predicts that social marketing may have a link with environmentally responsible behavior through visitors' outdoor recreation motivation.

Although the impact of the COVID-19 pandemic has been well evidenced in tourism research as a determinant of tourism behavior (i.e. Wen et al., 2020; Jiricka-Pürrer et al., 2020), research investigating the effect of COVID-19 risk perception on environmentally responsible behavior is still scant (Chi, 2021b). Severo et al. (2021) suggest that the COVID-19 pandemic is an important factor in behavioral change which reflects environmental and social responsibility in the study about residents in Brazil and Portugal. This research investigates how the impact of COVID-19 risk perception on visitors' outdoor recreation motivation and behavior can result in environmental responsibility. Reflecting on previous research related to the COVID-19 pandemic, it is suggested that COVID-19 risk perception may have some linkage with nature-based outdoor recreation motivation and environmentally responsible behavior.

To bridge these gaps within outdoor recreational activities, the current paper develops an integrated framework investigating these interrelationships. Vietnam is selected as an empirical context to test the proposed theoretical model. A study using the Vietnam context is relevant for this study, as it provides a setting for the development of effective strategies for promoting tourism in Vietnam and other developing countries in the future where the tourism sector has been under-developed. There are a lot of eco-destination sites in Vietnam which have already been proposed by UNESCO world heritage since 1993 (Tuoitrenews, 2020). However, the strategies for nature-based recreational activities development are insufficient. The purpose of this study is to examine the mediating role of motivation on outdoor recreation on the attitude-behavior and social marketing-behavior linkages, and especially to scrutinize the moderating impact of COVID-19 risk perception in transforming individual motivation on nature-based outdoor recreation into environmentally responsible behavior. Furthermore, this study also contributes several implications for management in the future. 


\section{Literature review}

\subsection{Outdoor recreation motivations}

The literature on consumer behavior revealed that motivation describes individual internal forces to a certain action (Schiffman and Kanuk, 1978). Colquitt et al. (2000) further argued that motivation is the process of the brain providing energy and behavior to an individual and a key factor for explaining individual behavior. From this respect, outdoor recreation motivations are seen as people's internal forces to engage in outdoor recreation.

There are different theories about recreation motivations such as the push-pull model (Le Core et al., 2021) and the REP-the recreation experience preference scale (Kura, 2021). Sisneros-Kidd et al. (2021) later confirmed travel motives in understanding the complex relationship between motivations and spatial behavior in parks and protected areas. Since Lundberg and Crompton's initial empirical effort, many researchers have attempted to find motivating factors. For example, Chi and Phuong (2021) confirmed tourists travel to seek something or to escape. Otherwise, the REP scale was used for various outdoor activities in examining psychological experiences (Chi, 2021a). Applying the REP scale, four types of outdoor recreation motives were used for investigating environmentally responsible behaviors which are knowledge-seeking, selfdevelopment, excitement and escape.

\subsection{Environmentally responsible behavior}

Environmentally responsible behavior (ERB) is referred to an individual's environmental concern, commitment and ecological knowledge (Gupta et al., 2021a, b). According to Oskamp (2002), ERB includes environmental activism, nonactivist behaviors in the public sphere and privatesphere environmentalism. ERB describes actions to reduce the negative influence on the environment (Lee et al., 2015; Matiza, 2020). This type of behavior has been assessed by numerous research studies. In the context of outdoor recreation, ERB results when people understand the impact of their behavior on the environment (Yilmaz and Anasori, 2021). This behavior toward outdoor activities is a consequence of environmental attitudes and behavioral norms (Lin and Lee, 2020) and promotes resource protection and actions to support the sustainable use of natural environments (Shi et al., 2019). ERB is considered as an eco-friendly or pro-environmental behavior (Liu et al., 2021). It can be concluded that ERB toward outdoor recreation is individual concern or actions toward ecological places, eco-tourism or other ecofriendly recreation activities.

\subsection{Environmental attitude and environmentally responsible behavior}

Attitude is "a psychological tendency that is expressed by evaluating a particular entity with some degree of favor or disfavor" (Eagly and Chaiken, 1993, p. 1) and beliefs and feelings about an object that causes one to behave consistently toward the object (Ajzen and Fishbein, 2000). Tao et al. (2004) also stated that environmental attitude is the stability of an individual towards environmental issues. They defined environmental attitude as appreciation for specific natural contexts. Other research stated attitudes about the protection and conservation of the environment and nature in general (Yilmaz and Anasori, 2021). Therefore, attitudes toward the natural environment are seen as individual beliefs and feelings about ecological activities which they behave toward the environment. Dunlap et al. (2000) proposed the new ecological paradigm (NEP) scale for measuring individual attitudes towards the environment. The first NEP scale was established in the 1970s by Dunlap and Van Liere (1978) having 12 items and focusing on three aspects of environmental attitudes. The second NEP scale was revised by Dunlap et al. (2000) having 15 items about the 5 aspects of ecological attitudes. This second version of the NEP scale has been employed in various areas including psychology, political science, sociology and geography (Pham and Chi, 2020).

There is a relationship between environmental attitude and ERB in the context of outdoor recreation (Kill et al., 2014). For example, Jurowski et al. (1995) reported that people having high

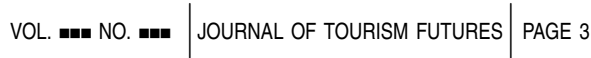


environmental attitudes pay attention to environmental protection by support for the allocated resources of Biscayne Bay National Park. The work of Lin and Lee (2020) focused on the expression of American tourists with a strong environmental attitude on less acceptance of environmental impacts. In addition, environmental attitudes are highly connected with environmental concern, knowledge and behavior toward ecological conservation (Gidlöf et al., 2021). The high level of environmental attitude is an important determinant to increase environmentally responsible tourism in the Australian Gold Coast (Perkins and Brown, 2012). More recently, Gupta et al. (2021a) addressed that people have become more environmental conscious after visiting ecological places. It can be suggested that the strong environmental attitude of visitors toward outdoor recreation activities is a predictor of support for their ERB.

\subsection{Social marketing and environmentally responsible behavior}

Social marketing has been employed extensively within the tourism industry (Hall, 2014) and outdoor recreation (Borden and Mahamane, 2020). According to Kotler and Zaltman (1971), social marketing is defined as influencing the acceptability of social ideas through product planning, pricing, communication, distribution and marketing research. Social marketing is considered the implementation of technologies to investigate the target customer behavior (Bright, 2000). Therefore, social marketing contributes to explaining customer behavior in outdoor recreation. Furthermore, social networks are Internet-based applications that allow customers to interact and to seek information (Nezakati et al., 2015). They argued that an individual is more integrated into the online environment through social media networks (i.e. Facebook, Instagram, Twitter, YouTube, etc.). Social networks offer different chances for firms in marketing their services and knowing customer demand. In line with these studies, social marketing in this paper has been described as the application of social network channels to do marketing campaigns for analyzing and evaluating customer behavior.

According to Beery et al. (2021), social marketing is a critical tool for changing people's behavior to promote health and protect the environment. The relationship between social marketing and customers' ERB is also analyzed as social marketing targets segments and evaluates customer behavior (Mckenzie-Mohr, 2000). The role of social marketing in delivering messages and determining the customers' persuasiveness has been investigated since the 1950s (i.e. Kelman and Hovland, 1953). This suggestion is applied to explain the customers' behavior (Craig and McCann, 1978). They found that people are likely to participate in outdoor recreation activities when they received a pamphlet from a highly credible source. Goldsmith et al. (2000) examined the effects of social advertisement on consumer attitude and their purchasing behavior and revealed that this effect is significant. More recently, Inoue and Kent (2014) proposed the framework for understanding the impact of social marketing on consumer behavior. Based on these findings, this current paper posits that social marketing is likely to have a positive influence on customers' ERB toward outdoor recreation.

\subsection{The relationship between environmental attitude and environmentally responsible behavior through outdoor recreation motivation}

The relationship between attitude and behavior is proposed by the theory of planned behavior (TPB) (Ajzen, 1991) and value-belief-norm (VBN) theory (Kaiser et al., 2005; Stern, 2000). Following the TPB of Aizen (1991), motivation is captured by intention and influences behavior which shows the individual effort to perform the behavior. VBN theory suggested that people with strong environmental attitudes are more pushed to behave more responsible manner (Chiu et al., 2014). In general, people with a high level of environmental attitude are likely to be motivated in engaging outdoor recreation.

In discussing the relationship between motivation and attitude, Gnoth (1997) proposed the conceptual study in which travel motivation positively impacts tourist attitude. An individual having environmental attitudes is motivated to attend outdoor recreation activities such as a film or video- 
related international festival in Brazil (Kim et al., 2006). Otherwise, Huang and Hsu (2009) further addressed that tourist motivation affects tourist revisit intention through tourist attitude since motivation is an initial driving force behind behavior. As tourists have an attitude towards the environment, Zhang and Lei (2012) argued that environmental knowledge contributes to travel motivation and intention to visit. They suggested that motivation was a predictor of revisit intention while environmental knowledge could be assumed equivalent to attitude. Kil et al. (2014) suggested that motivation is a channel of transition from an individual's environmental attitude to their responsible behavior towards the natural environment. Therefore, the current paper continues to examine the role of motivation toward outdoor recreation in the relationship between factors (i.e. environmental attitudes, social marketing) and ERB.

\subsection{Relationship between social marketing and environmentally responsible behavior through outdoor recreation motivation}

According to Foxall et al. (2006), social marketing in isolation is unlikely to provide understanding the way in which customer's behavior impacts on the environment. This is because social marketing is a short-term activity while environmental issues have long-term duration and effect. Moreover, the advertisement had a direct effect on advertisement credibility and attitudes toward the advertiser, and indirect effects on attitude toward the advertisement through the mediation of the two variables (MacKenzie and Lutz, 1989).

There is a great interest in examining the effect of social marketing on consumers' ERB through their motivation toward outdoor recreation. Oliveira et al. (2020) currently reveal that social marketing makes customers express their experiences on online networks and also makes them feel more excited about engaging in outdoor recreation activities. They argue that marketing on social media influences the drivers of motivations as more and more tourists are turning to the online travel community to undertake their travel-related tasks. In other studies, Borden and Mahamane (2020) have referred to travel purchasing intention and travel motivation for engaging in outdoor recreational advocacy. Outdoor recreation motivations attract tourists to travel and to select a destination (Tkaczynski et al. , 2020). Moreover, motivation is also used in social marketing to predict and explain behavior change toward galamsey activities in Ghana (Tkaczynski et al., 2020). Given the implications of social marketing explained above, this study proposes that outdoor recreation motivation mediates the relationship between social marketing and consumers' ERB.

\subsection{The moderating role of coronavirus disease 2019 risk perception}

Risk perception is viewed as value judgments relating to uncertain situations rising from a particular risk (Bauer, 1960; Matiza, 2020). As risk perception is the major predictor of behavior, many studies investigate the concept of perceived risk (Dillard et al., 2012). Risk perception includes two dimensions (i.e. cognitive and affective) (Brug et al., 2004). The cognitive dimension focuses on individual perceived susceptibility and severity of risk while the affective dimension focuses on individual anxiety about their exposure to risk (Sjöberg, 1998; Higgins-Desbiolles et al., 2021). An earlier study has addressed the impact of affective risk perception on behavior (Loewenstein et al. , 2001) while more recent research focused on the cognitive aspect (Jones and Nguyen, 2021; Gupta et al. , 2021 b). In outdoor recreation, risk has been investigated as a key factor influencing international tourists (Landry et al., 2021; Chi, 2021b). More especially, outdoor recreation makes visitors take higher unsystematic risks (Spennemann and Whitsed, 2021; Mkono, 2020). COVID-19 risk perception in outdoor recreation is seen as people's perception of the probability that engaging in outdoor recreation may expose them to COVID-19 danger. In travel behavior, risk perception varies according to destinations (Khan et al., 2017).

In mentioning the relationship between motivation, risk perception and behavior, tourism studies have examined perceived risk and its impact on visitors' behavior toward outdoor recreation since 
the 1990s (Huang et al., 2020). As a serious disease like COVID-19 has significantly impacted the tourism industry, the impact of COVID-19 pandemic has drawn wide attention (Bae and Chang, 2020). Rosenstock (1974) considered perceived risk as a critical component in predicting behavior. People perceiving a certain risk are likely to participate in preventive health behaviors to avoid health risks (Chen et al., 2017). Moreover, Janmaimool (2017) revealed that people participating in a threatening event are motivated to engage in protective behavior. This theory proposed factors to explain ERB including perceived risk, motivation and preventive behavior. It can be concluded that individual who perceives the COVID-19 risk is assumed to have more ERB to minimize health risks.

\subsection{Hypotheses}

Drawing from the results of previous studies, environmental attitudes and social marketing are likely the two predictors of investigating ERB with the moderating role of COVID-19 risk perception and the mediating role of outdoor recreation. Therefore, the current paper proposes to examine the following hypotheses (Figure 1):

H1a. Environmental attitude positively impacts outdoor recreation motivation

H1b. Environmental attitude positively impacts ERB

H2a. Social marketing positively impacts outdoor recreation motivation

H2b. Social marketing positively impacts ERB

H3. Outdoor recreation motivation positively impacts ERB

H4. COVID-19 risk perception positively moderates the relationship between outdoor recreation motivation and ERB.

\section{Methods}

\subsection{Study area}

Cuc Phuong is located in Ninh Binh Province, in Vietnam's Red River Delta. Cuc Phuong was the first national park and is Vietnam's largest nature reserve which is one of the most important sites for biodiversity in Vietnam. Cuc Phuong is situated in the foothills of the northern Annamite Range. The park consists of verdant karst mountains and lush valleys. Elevation varies from 150 meters (500 feet) to $656 \mathrm{~m}$ (2,152 feet) at the summit of May Bac Mountain or Silver Cloud Mountain (Hogle, 2021). The limestone mountains house numerous caves, many of which are accessible for exploration. Cuc Phuong is home to an amazing diversity of flora and fauna. Several species in the park are listed on the Vietnam Red Book of endangered species.

\section{Figure 1 The theoretical framework}

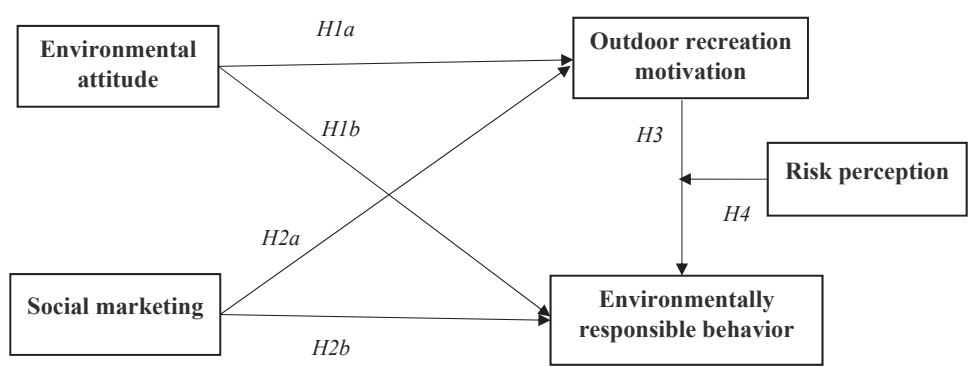




\subsection{Variable measurement}

This study measures the theoretical constructs in the proposed model which were validated by previous research. COVID-19 risk perception was measured by five items from the research of Bae and Chang (2020). Outdoor recreation motivation is captured using five items adopted from Kil et al. (2014). Meanwhile, environmental attitudes were employed by four items which conform to the studies of Kil et al. (2014). Social marketing was measured by four items and adopted from Borden and Mahamane (2020) and Bedard and Tolmie (2018). ERB was measured by five items from the research of Kil et al. (2014). This study employed a five-point Likert scale for measuring study questions which range from (strongly disagree) to 5 (strongly agree) for all items in this study.

Before data collection, there are two rounds of pre-tests performed on the questionnaire. First, the questionnaire was filled out by five experts who are lecturers of three universities in Vietnam and are specializing in tourism management. After that, the wording of questions in the questionnaires was modified to ensure clarity based on experts' feedback. The judgmental approach to establish content validity involves literature reviews and then follow-ups with the evaluation by expert judges or panels (Straub et al., 2004). Second, the questionnaire was also pre-tested with 60 Vietnamese visitors at the main gate of the Hanoi landscape. Cronbach's alpha is used to evaluate the data from this pilot test. The results show that all items of research constructs are adequately reliable (each construct has Cronbach's alpha coefficient from 0.70 to 0.85 ). Therefore, the validity and reliability of the survey questionnaire are ensured. The final version of the questionnaire was translated into Vietnamese by a professional translator and reviewed by a language editor to make sure the accuracy of the translated version.

\subsection{Data collection and sampling}

The target sample of this study is Vietnamese visitors to the ecological place. Data are collected at Cuc Phuong National Park in the North West of Vietnam. Each visitor was directly and kindly requested to engage in answering the questionnaire by means of a mall-intercept survey. According to Awuni and Du (2016), the sampling method has been employed in other markets. In this study, hotels nearby Cuc Phuong are randomly selected where one out of every three patrons was selected randomly. The participants were introduced to the objective and also assured that their information would be kept confidential and used only for research purposes. After four months, more than 900 respondents were kindly approached for asking to join the survey. Ten assistants were recruited to launch questionnaires. The process was strictly controlled and supervised by the author. The survey was undertaken from June to September 2020 using structured questionnaires. The valid surveys were returned and completed at 625 which represents a retrieval rate of $69.4 \%$.

Within the sample of participants, males accounted for $50.2 \%$ and females accounted for $49.8 \%$ representing an almost equal distribution of gender. The majority of visitors in the sample were from $31-40$ years old (46.6\%) and business (34.6\%). The vast majority of consumers who completed the questionnaire had an income per month of 500-1,000 USD/month (25.4\%).

\subsection{Data analysis}

In order to test the proposed model, a three-stage approach was employed. First, confirmatory factor analysis (CFA) recommended by Hair et al. (2010a, b) was used to validate the measurement scale. Second, "Structural equation modelling-SEM" adopted by Anderson and Gerbing (1988) was assessed for the relationships among environmental attitude, social marketing, outdoor recreation motivation and ERB by the support of AMOS 21.0. The model fit indices $\left(\chi^{2} / \mathrm{df}\right.$, GFI, TLI, $\mathrm{NFI}, \mathrm{CFI}$ and RMSEA were examined (Kline, 2005). Third, PROCESS macro in SPSS 21.0 was employed for analyzing the moderating impact of risk perception on the relationship between outdoor recreation motivation and ERB. 
To test the normality of the observed constructs, the kurtosis indices through Mardia index (Mardia, 1971) and Pearson asymmetric coefficient (Severo et al., 2015), sample means and variances multi-normality were employed. Furthermore, multivariate outliers by Mahalanobis calculation were used (Kline, 2005). The results found that all variables are univariate normally distributed.

\section{Results}

\subsection{Measurement model testing}

To test the possibility of common methods bias by following Podsakoff et al. (2003), this research employs two tests i.e. Harman's one-factor and CFA. First, all the variables were tested using CFA and no single factor emerged nor did it account for the majority of the variance. As a result, no general factor is apparent. Second, a CFA model was run whereby all the variables were allocated to one factor. In examining the model fit, the analysis revealed that the single-factor model did not fit the data well. The results suggest that common method bias is not of concern and is unlikely to confound the interpretations of the paper's results.

The measurement model exhibited a good fit as the test indices indicated a satisfactory fit $\left(\chi^{2} / \mathrm{df}=2.830\right.$ and RMSEA $\left.=0.052\right)$ (Hair et al., 2014). The model fit indices (CFI $=0.931$, $\mathrm{GFI}=0.919, \mathrm{TLI}=0.919$ and IFI $=0.931$ ) were above the cutoff requirement of 0.90 (Kline, 2015). All the indices were significant at $p<0.001$ (Table 1).

Table 1 The reliability and convergent validity

\begin{tabular}{|c|c|c|c|c|}
\hline Constructs/variables & $\begin{array}{l}\text { Standard } \\
\text { loadings }\end{array}$ & $\begin{array}{l}\text { Cronbach's } \\
\text { alpha }\end{array}$ & $\begin{array}{l}\text { Composite } \\
\text { reliability }\end{array}$ & AVE \\
\hline COVID-19 Risk perception & & 0.821 & 0.841 & 0.52 \\
\hline I am worried that I will contract COVID-19 & 0.663 & & & \\
\hline I am worried about COVID-19 occurring in my region & 0.623 & & & \\
\hline There is a high likelihood of acquiring COVID-19 compared to other diseases & 0.716 & & & \\
\hline There is a high likelihood of dying from COVID-19 & 0.793 & & & \\
\hline I am worried about COVID-19 emerging as a health issue & 0.786 & & & \\
\hline Environmental attitudes & & 0.822 & 0.826 & 0.54 \\
\hline The Earth has plenty of natural resources if we just learn how to develop them & 0.678 & & & \\
\hline Plants and animals have as much right as humans to exist & 0.755 & & & \\
\hline The balance of nature is very delicate and easily upset & 0.804 & & & \\
\hline $\begin{array}{l}\text { If things continue on their present course, we will soon experience a major } \\
\text { ecological catastrophe }\end{array}$ & 0.705 & & & \\
\hline Outdoor recreation motivation & & 0.781 & 0.853 & 0.54 \\
\hline Enjoy the scenery & 0.732 & & & \\
\hline Experience nature & 0.752 & & & \\
\hline Be close to nature & 0.756 & & & \\
\hline Explore the area & 0.778 & & & \\
\hline Experience new and different things & 0.645 & & & \\
\hline Social marketing & & 0.795 & 0.808 & 0.51 \\
\hline $\begin{array}{l}\text { I would be influenced to engage in outdoor recreation that advertised in social } \\
\text { networks }\end{array}$ & 0.645 & & & \\
\hline Social marketing about outdoor activities make the poster stand out & 0.704 & & & \\
\hline Social marketing makes me more understanding about outdoor activities & 0.793 & & & \\
\hline I seek information about outdoor recreation activities from social marketing & 0.717 & & & \\
\hline Environmentally responsible behavior & & 0.737 & 0.845 & 0.52 \\
\hline Subscribed to environmental publications & 0.631 & & & \\
\hline Voted for a public official due to his/her record on protecting the environment & 0.772 & & & \\
\hline $\begin{array}{l}\text { Donated money or paid membership due to an environmental/conservation } \\
\text { organization }\end{array}$ & 0.671 & & & \\
\hline $\begin{array}{l}\text { Written to your elected officials expressing your opinions on environmental } \\
\text { issues }\end{array}$ & 0.766 & & & \\
\hline Find information about the environment & 0.769 & & & \\
\hline
\end{tabular}


The composite reliability estimate of each construct was also satisfactory as it was above 0.700 (Nunnally and Bernstein, 1994) which also indicated all constructs' reliability. All the standard factor loadings were more than the required cutoff limit of 0.50 (Tabachnick and Fidell, 2013). The average variance extracted (AVE) of each construct was also above 0.50 which established convergent validity (Fornell and Larcker, 1981) (Table 1). Furthermore, Table 2 showed that the squared AVE (square root of AVE of each construct) was larger than the correlation coefficient. Table 3 confirmed the existence of discriminant validity and showed the uniqueness and distinctness of research constructs (Hair et al., 2014).

\subsection{Structural model testing}

Table 3 shows the path analysis results using SEM on the whole sample. As can be seen from Table 3, the baseline model has a good fit $\left(\chi^{2} / d f=3.723 ; C F I=0.910 ; T L I=0.900 ; I F I=0.911\right.$; RMSEA $=0.066$ ). The hypothesized relationships are all statically significant and positive except for $\mathrm{H} 2 \mathrm{~b}$. Therefore, the hypotheses H1a, H1b, H2a and H3 are accepted.

Environmental attitudes and social marketing all positively affect outdoor recreation motivation (0.358 and 0.357 , respectively), while only environmental attitude has a direct impact on ERB (0.490). Social marketing has an indirect influence on ERB through outdoor recreation motivation.

In order to assess the total impact of all factors in the model, the direct-indirect total effect analysis was employed. Table 4 shows that two constructs (environmental attitudes and social marketing) have directly linked with outdoor recreation motivation while they have both direct and indirect effect on ERB. The total effect of environmental attitudes on ERB is largest at 0.654 (sum of direct

\section{Table 2 Discriminant validity}

\begin{tabular}{lcccc} 
Constructs & Environmental attitudes & Social marketing & Outdoor motivation & Risk perception \\
\hline Environmental attitudes & 0.735 & & & Behavior \\
Social marketing & 0.596 & 0.714 & 0.735 & 0.721 \\
Motivation & 0.543 & 0.444 & 0.621 & 0.718 \\
Risk perception & 0.716 & 0.692 & 0.708 & 0.721 \\
Behavior & 0.713 & 0.557 & & \\
Note(s): AVE-average variance extracted & & &
\end{tabular}

\section{Table 3 Path analysis results of the baseline model}

\begin{tabular}{|c|c|c|c|}
\hline Relationships & Path coefficient & $\mathrm{p}$ & Test result \\
\hline H1a: Environmental attitudes $\rightarrow$ Outdoor recreation motivation & 0.358 & *** & Supported \\
\hline H2a: Social marketing $\rightarrow$ Outdoor recreation motivation & 0.357 & $\star \star \star ~$ & Supported \\
\hline H3: Outdoor recreation motivation $\rightarrow$ Environmentally responsible behavior & 0.457 & 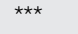 & Supported \\
\hline H1b: Environmental attitudes $\rightarrow$ Environmentally responsible behavior & 0.490 & $\star \star \star ~$ & Supported \\
\hline H2b: Social marketing $\rightarrow$ Environmentally responsible behavior & 0.203 & 0.07 & Not supported \\
\hline Note(s): ${ }^{\star \star \star}<0.001$ & & & \\
\hline
\end{tabular}

Table 4 Direct, indirect and total effect coefficients

\begin{tabular}{lccc} 
Path & Direct effect & Indirect effect & Total effect \\
\hline Environmental attitudes $\rightarrow$ Outdoor recreation motivation & 0.357 & 0.000 & 0.357 \\
Social marketing $\rightarrow$ Outdoor recreation motivation & 0.358 & 0.000 & 0.358 \\
Environmental attitudes $\rightarrow$ Environmentally responsible behavior & 0.490 & 0.164 & 0.654 \\
Social marketing $\rightarrow$ Environmentally responsible behavior & 0.000 & 0.163 & 0.163 \\
Outdoor motivation $\rightarrow$ Environmentally responsible behavior & 0.457 & 0.000 & 0.457
\end{tabular}


and indirect impact through outdoor recreation motivation). Meanwhile, the total effect of social marketing on behavior is 0.163 which is the lowest among the two predictors.

\subsection{The moderating role of social networks}

The analysis of moderating effect of risk perception was employed by using process macro in SPSS 21.0. The results show that the impact of COVID-19 risk perception enhances the relationship between outdoor recreation motivation and ERB. Therefore, $\mathrm{H} 4$ is supported.

Table 5 showed that COVID-19 risk perception plays the moderating role to increase the relationship between outdoor recreation motivation and ERB.

\section{Discussion}

The current paper proposed a framework that investigates the impact of social marketing and environmental attitude on ERB with the role of nature-based outdoor recreation motivation and COVID19 risk perception. The results mostly support the proposed hypotheses. First, the tourists' environmental attitude towards national parks has significantly impacted their ERBs (direct effect at 0.490 , indirect effect at 0.164 , total effect at 0.654 ). This finding confirms the results of previous research such as the work of Jurowski et al. (1995) while is far different from other scholars. For example, Chan (2019) indicated that being a mindful person shows a more sustainable attitude but it does not affect ERB significantly. Wearing and McDonald (2002) suggested the relationship between environmental attitude and environmental purchasing behavior in tourism destinations in a study of international backpackers in Australia. However, the finding in this study, which suggests the link between social marketing and ERB (indirect effect at 0.163), is in contrast with Mckenzie-Mohr (2000) and Inoue and Kent (2014). They argued that social marketing has a direct effect on consumer behavior.

Second, the study's results also lend some support to the influences of motivation as a mediating factor in transforming social marketing and environmental attitude into factors pushing ERB. The results (Table 4) also confirm that social marketing and visitors' environmental attitudes have indirect ERB toward outdoor recreation through their motivation which is in agreement with previous studies. People who are motivated to visit natural destinations will have ERB. This current study tests whether the individual motivation for engaging in nature-based outdoor recreation has a mediating effect on the environmental attitude-behavior link and the social marketing-behavior relationship. The mediating role of motivation in the link between attitude and behavior is similar to previous studies with outdoor recreational activities (i.e. Kil et al., 2014; Kerstetter et al., 2004; Osbaldiston and Sheldon, 2003).

The study's findings also suggest the indirect effect of social marketing on ERB through motivation (H2b). This finding is in accordance with the findings of Tweneboah-Koduah et al. (2020) which demonstrated the role of social marketing in explaining behavior change through customer motivation. However, the study's results do not mention the direct impact of social marketing on ERB. This is somewhat different from Tweneboah-Koduah et al. (2020) which reveal social marketing as the predictor in understanding the waste disposal behavior among households in Ghana. In the context of recreation activities, Borden and Mahamane also suggest the direct link between social marketing and ERP. Unfortunately, in the context of an emerging country, the social marketing tool is effective to improve the ERP of the visitors through finding their outdoor recreation motivation.

Finally, this paper positions COVID-19 risk perception as the critical moderating input which has not been examined in previous recreation research. The result of this work (Table 5) confirms that

\section{Table 5 The results of the moderating effect of social networks}

\begin{tabular}{lcccccl} 
Path & $\beta$ & $\mathrm{t}$ & $\mathrm{p}$ & $\mathrm{LLCl}$ & $\mathrm{ULCl}$ & Moderation \\
\hline $\mathrm{H} 4: \mathrm{RIK} \times \mathrm{MOV} \rightarrow \mathrm{BHV}$ & 0.036 & 0.853 & 0.028 & 0.094 & 0.132 & Yes
\end{tabular}

Note(s): $\beta=$ standardized regression weight, $t=t$ value, $\mathrm{LLCl}=$ lower limit of confidence interval, $\mathrm{ULCl}=$ upper limit of confidence interval. $\mathrm{RIK} \times \mathrm{MOV}=$ interaction between risk perception and outdoor recreation motivation 
COVID-19 risk perception can be regarded as a critical effect in enhancing the influence of naturebased outdoor recreation motivation on tourists' ERB. This new finding is similar to those of previous studies applying PMT (protection motivation theory) (Janmaimool, 2017; Chen et al., 2017; Bae and Chang, 2020; Huang et al., 2020). Therefore, this paper suggests that people who perceive COVID-19 risk and have the motivation to nature-based outdoor recreational activities will have ERB to minimize the risk affecting their health.

\section{Conclusion}

Based on the above discussion, the paper offers several theoretical implications. First, this study confirms that outdoor recreation activities and business marketing on social networks tend to transform into support for individual behavior in terms of protecting the environment and having responsibility for the environment. The business's social marketing, visitors' environmental attitudes and visitors' motivation are the important factors impacting visitors' behavior in any efforts of environmental protection. This also helps to sustain visitors' ecological behavior in the natural environment in the future. Second, the current paper also represents the academic efforts to contribute to outdoor recreation literature by explaining the current global problem that has caused serious upheaval in global society as well as individual life. The study's findings will offer a critical reference point for future studies in examining visitors' behavior in the short-term and long-term as responding to the call of Gössling et al. (2020) and Rice et al. (2020). Third, the paper expanded the planned behavior and protection motivation theories with the variables of COVID-19 risk perception, motivation and behavior. The findings not only confirm the mediating role of nature-based outdoor recreation motivation between attitude and behavior but also examine the moderating effect of COVID-19 risk perception in the relationship between motivation and behavior. Epidemiologically, it is predictable that another zoonotic coronavirus will manifest itself in the foreseeable future (Peeri et al., 2020). Therefore, these results will provide key insights about examining visitors' behavior for environmental protection during future infectious disease outbreaks.

This paper also contributes to practical implications for the outdoor recreation and tourism industry in Vietnam as well as other developing countries. Recreation providers need to apply social marketing efforts to their supporting, operations or empowering to evoke customers' outdoor recreation motivation in the future. For example, they may consider a social marketing strategy on the channel of social networks (i.e. YouTube, Facebook, Twitter, Pinterest, etc.) for attracting new customers and retaining the existing visitors. Besides improving communication, recreation providers should increase nature-based recreation and diversify nature-based recreational services to attract new visitors. Managers' positive outlook and dynamic response were very much in the spirit of proactive climate adaptation, i.e. efforts to respond to change to meet current needs while planning for ongoing or projected future challenges. As suggested in the research's findings, people with a high level of environmental attitudes and a positive perception of social marketing can potentially contribute to political support for environmental protection. Therefore, policymakers can enlist people's support of the natural environment to call for actions to protect the environment and public health in the future. In addition, as COVID-19 will be repeated every four to five years due to environmental changes (Kim and Su, 2020), tourism and recreation providers need to consider nature-based tourism for minimizing visitors' perceived risks and satisfy their need for traveling. People may join nature-based tourism in a small group.

The study has some limitations that associate with a single country context and cross-sectional survey data. Future research should use a country context different from Vietnam to revalidate this paper's findings. A different research design is also suggested, such as using two phases of data collection or experimental research, to examine the relationships proposed in this study. Next, this research is restricted in analyzing the control variables which may make researchers misunderstand the results. Therefore, future research should consider the control variables. Finally, this study only examines the association between social marketing, motivation and ERB. Future research might study other factors which perhaps have links with social marketing and behavior towards outdoor recreation. 


\section{References}

Ajzen, I. and Fishbein, M. (2000), "Attitudes and the attitude-behavior relation: reasoned and automatic processes”, European Review of Social Psychology, Vol. 11 No. 1, pp. 1-33.

Ajzen, I. (1991), "The theory of planned behavior", Organizational Behavior and Human Decision Processes, Vol. 50 No. 2, pp. 179-211.

Anderson, J.C. and Gerbing, D.W. (1988), "Structural equation modeling in practice: a review and recommended two-step approach", Psychological Bulletin, Vol. 103 No. 3, p. 411.

Awuni, J.A. and Du, J. (2016), "Sustainable consumption in Chinese cities: green purchasing intentions of young adults based on the theory of consumption values", Sustainable Development, Vol. 24 No. 2, pp. 124-135.

Bae, S.Y. and Chang, P.J. (2020), "The effect of coronavirus disease-19 (COVID-19) risk perception on behavioural intention towards 'untact' tourism in South Korea during the first wave of the pandemic (March 2020)", Current Issues in Tourism, Vol. 24 No. 7, pp. 1017-1035.

Bauer, R.A. (1960), "Consumer behavior as risk taking", Proceedings of the 43rd National Conference of the American Marketing Association, June 15-17, American Marketing Association, Chicago, Illinois.

Bedard, S.A.N. and Tolmie, C.R. (2018), "Millennials' green consumption behaviour: exploring the role of social media", Corporate Social Responsibility and Environmental Management, Vol. 25 No. 6, pp. 1388-1396.

Beery, A.K., Lopez, S.A., Blandino, K.L., Lee, N.S. and Bourdon, N.S. (2021), "Social selectivity and social motivation in voles", Elife, Vol. 10, e72684.

Borden, D.S. and Mahamane, S. (2020), "Social marketing and outdoor recreational advocacy groups: lessons from a rock climbing campaign", Journal of Outdoor Recreation and Tourism, Vol. 29, p. 100262.

Bright, A.D. (2000), "The role of social marketing in leisure and recreation management", Journal of Leisure Research, Vol. 32 No. 1, pp. 12-17.

Brug, J., Aro, A.R., Oenema, A., De Zwart, O., Richardus, J.H. and Bishop, G.D. (2004), "SARS risk perception, knowledge, precautions, and information sources, The Netherlands", Emerging Infectious Diseases, Vol. 10 No. 8, p. 1486.

Chan, E.Y. (2019), "Mindfulness promotes sustainable tourism: the case of Uluru", Current Issues in Tourism, Vol. 22 No. 13, pp. 1526-1530.

Chen, J., Wu, H., Qian, H. and Gao, Y. (2017), "Assessing nitrate and fluoride contaminants in drinking water and their health risk of rural residents living in a semiarid region of northwest China", Exposure and Health, Vol. 9 No. 3, pp. 183-195.

Chi, N.T.K. and Phuong, V.H. (2021), "Studying tourist intention on city tourism: the role of travel motivation", International Journal of Tourism Cities, Vol. ahead-of-print No. ahead-of-print.

Chi, N.T.K. (2021a), "Understanding the effects of eco-label, eco-brand, and social media on green consumption intention in ecotourism destinations", Journal of Cleaner Production, Vol. 321, p. 128995.

Chi, N.T.K. (2021b), "Innovation capability: the impact of e-CRM and COVID-19 risk perception”, Technology in Society, Vol. 67, p. 101725.

Chiu, Y.T.H., Lee, W.I. and Chen, T.H. (2014), "Environmentally responsible behavior in ecotourism: antecedents and implications", Tourism Management, Vol. 40, pp. 321-329.

Colquitt, J.A., LePine, J.A. and Noe, R.A. (2000), "Toward an integrative theory of training motivation: a meta-analytic path analysis of 20 years of research", Journal of Applied Psychology, Vol. 85 No. 5, p. 678.

Craig, C.S. and McCann, J.M. (1978), "Assessing communication effects on energy conservation”, Journal of Consumer Research, Vol. 5 No. 2, pp. 82-88.

Dillard, A.J., Ferrer, R.A., Ubel, P.A. and Fagerlin, A. (2012), "Risk perception measures' associations with behavior intentions, affect, and cognition following colon cancer screening messages", Health Psychology, Vol. 31 No. 1, p. 106

Dunlap, R.E. and Van Liere, K.D. (1978), "The 'new environmental paradigm'”, The Journal of Environmental Education, Vol. 9 No. 4, pp. 10-19.

Dunlap, R.E., Van Liere, K.D., Mertig, A.G. and Jones, R.E. (2000), "New trends in measuring environmental attitudes: measuring endorsement of the new ecological paradigm: a revised NEP scale", Journal of Social Issues, Vol. 56 No. 3, pp. 425-442. 
Eagly, A.H. and Chaiken, S. (1993), The Psychology of Attitudes, Harcourt brace Jovanovich college publishers, San Diego, California.

Fornell, C. and Larcker, D.F. (1981), "Evaluating structural equation models with unobservable variables and measurement error: algebra and statistics", Journal of Marketing Research, Vol. 18 No. 3, pp. 382-388.

Foxall, G.R., Oliveira-Castro, J.M., James, V.K., Yani-de-Soriano, M.M. and Sigurdsson, V. (2006), "Consumer behavior analysis and social marketing: the case of environmental conservation", Behavior and Social Issues, Vol. 15 No. 1, pp. 101-125.

Gidlöf, K., Lahm, E.S., Wallin, A. and Otterbring, T. (2021), "Eco depletion: the impact of hunger on prosociality by means of environmentally friendly attitudes and behavior", Journal of Retailing and Consumer Services, Vol. 62, p. 102654.

Gnoth, J. (1997), "Tourism motivation and expectation formation", Annals of Tourism Research, Vol. 24 No. 2, pp. 283-304.

Gössling, S., Scott, D. and Hall, C.M. (2020), "Pandemics, tourism and global change: a rapid assessment of COVID-19", Journal of Sustainable Tourism, Vol. 29 No. 1, pp. 1-20.

Goldsmith, D.J., McDermott, V.M. and Alexander, S.C. (2000), "Helpful, supportive and sensitive: measuring the evaluation of enacted social support in personal relationships", Journal of Social and Personal Relationships, Vol. 17 No. 3, pp. 369-391.

Gordon, R., Dibb, S., Magee, C., Cooper, P. and Waitt, G. (2018), "Empirically testing the concept of value-inbehavior and its relevance for social marketing", Journal of Business Research, Vol. 82, pp. 56-67.

Gupta, A., Arora, N., Sharma, R. and Mishra, A. (2021a), "Determinants of tourists' site-specific environmentally responsible behavior: an eco-sensitive zone perspective", Journal of Travel Research, Vol. 64 No. 2, pp. 1-20, doi: 10.1177/00472875211030328.

Gupta, V., Cahyanto, I., Sajnani, M. and Shah, C. (2021b), "Changing dynamics and travel evading: a case of Indian tourists amidst the COVID 19 pandemic", Journal of Tourism Futures, Vol. ahead-of-print No. aheadof-print, doi: 10.1108/JTF-04-2020-0061.

Hair, J.F., Black, W.C., Babin, B.J. and Anderson, R.E. (2010a), Multivariate Data Analysis, 7th ed., PrenticeHall, NJ.

Hair, J.F., Black, W.C., Babin, B.J. and Anderson, R.E. (2010b), Canonical Correlation: A Supplement to Multivariate Data Analysis. Multivariate Data Analysis: A Global Perspective, 7th ed., Pearson Prentice Hall Publishing, Upper Saddle River, NJ.

Hair, J.F., Jr., Sarstedt, M., Hopkins, L. and Kuppelwieser, V.G. (2014), "Partial least squares structural equation modeling (PLS-SEM): an emerging tool in business research", European Business Review, Vol. 26 No. 2, pp. 106-121.

Hall, C.M. (2014), Tourism and Social Marketing, Routledge.

Higgins-Desbiolles, F., Bigby, B.C. and Doering, A. (2021), "Socialising tourism after COVID-19: reclaiming tourism as a social force?", Journal of Tourism Futures, Vol. ahead-of-print No. ahead-of-print, doi: 10.1108/ JTF-03-2021-0058.

Høyem, J. (2020), "Outdoor recreation and environmentally responsible behavior", Journal of Outdoor Recreation and Tourism, Vol. 31, p. 100317.

Hogle, L. (2021), "Cuc Phuong national park- Ninh Binh province”, available at: https://www.uncovervietnam. com/cuc-phuong-national-park-ninh-binh/ (accessed 07 September 2021).

Huang, S. and Hsu, C.H. (2009), "Effects of travel motivation, past experience, perceived constraint, and attitude on revisit intention", Journal of Travel Research, Vol. 48 No. 1, pp. 29-44.

Huang, X., Dai, S. and Xu, H. (2020), "Predicting tourists' health risk preventative behaviour and travelling satisfaction in Tibet: combining the theory of planned behaviour and health belief model", Tourism Management Perspectives, Vol. 33, p. 100589.

Humagain, P. and Singleton, P.A. (2021), "Examining relationships between COVID-19 destination practices, value, satisfaction and behavioral intentions for tourists' outdoor recreation trips", Journal of Destination Marketing and Management, Vol. 22, p. 100665.

Inoue, Y. and Kent, A. (2014), "A conceptual framework for understanding the effects of corporate social marketing on consumer behavior", Journal of Business Ethics, Vol. 121 No. 4, pp. 621-633. 
Janmaimool, P. (2017), "Application of protection motivation theory to investigate sustainable waste management behaviors", Sustainability, Vol. 9 No. 7, p. 1079.

Jiricka-Pürrer, A., Brandenburg, C. and Pröbstl-Haider, U. (2020), "City tourism pre-and post-Covid-19 pandemic-Messages to take home for climate change adaptation and mitigation?", Journal of Outdoor Recreation and Tourism, Vol. 31, p. 100329.

Jones, T. and Nguyen, M.H. (2021), "COVID-19 early stage social acceptance of entry restrictions for international tourists to Japan", Journal of Tourism Futures, Vol. ahead-of-print No. ahead-of-print, doi: 10. 1108/JTF-03-2021-0058.

Jurowski, C., Uysal, M., Williams, D.R. and Nog, F.P. (1995), "An examination of preferences and evaluations of visitors based on environmental attitudes: biscayne Bay National Park", Journal of Sustainable Tourism, Vol. 3 No. 2, pp. 73-86.

Kaiser, F.G., Hübner, G. and Bogner, F.X. (2005), "Contrasting the theory of planned behavior with the valuebelief-norm model in explaining conservation behavior 1", Journal of Applied Social Psychology, Vol. 35 No. 10 , pp. 2150-2170.

Kelman, H.C. and Hovland, C.I. (1953), "Reinstatement of the communicator in delayed measurement of opinion change", The Journal of Abnormal and Social Psychology, Vol. 48 No. 3, p. 327.

Kerstetter, D.L., Hou, J.S. and Lin, C.H. (2004), "Profiling Taiwanese ecotourists using a behavioral approach", Tourism Management, Vol. 25 No. 4, pp. 491-498.

Khan, M.J., Chelliah, S. and Ahmed, S. (2017), "Factors influencing destination image and visit intention among young women travellers: role of travel motivation, perceived risks, and travel constraints", Asia Pacific Journal of Tourism Research, Vol. 22 No. 11, pp. 1139-1155.

Kil, N., Holland, S.M. and Stein, T.V. (2014), "Structural relationships between environmental attitudes, recreation motivations, and environmentally responsible behaviors", Journal of Outdoor Recreation and Tourism, Vol. 7, pp. 16-25.

Kim, S.W. and Su, K.P. (2020), "Using psychoneuroimmunity against COVID-19", Brain, Behavior, and Immunity, Vol. 87, pp. 4-5.

Kim, H., Borges, M.C. and Chon, J. (2006), "Impacts of environmental values on tourism motivation: the case of FICA, Brazil”, Tourism Management, Vol. 27 No. 5, pp. 957-967.

Kline, T. (2005), Psychological Testing: A Practical Approach to Design and Evaluation, Sage, Thousand Oaks, California.

Kline, R.B. (2015), Principles and Practice of Structural Equation Modeling, Guilford publications, New York City.

Komossa, F., Wartmann, F.M., Kienast, F. and Verburg, P.H. (2020), "Comparing outdoor recreation preferences in peri-urban landscapes using different data gathering methods", Landscape and Urban Planning, Vol. 199, p. 103796.

Kotler, P. and Zaltman, G. (1971), "Social marketing: an approach to planned social change", Journal of Marketing, Vol. 35 No. 3, pp. 3-12.

Kurar, i. (2021), "Research on the determination of recreational experience preferences, expectations, and satisfaction levels of local people", International Journal of Entrepreneurial Knowledge, Vol. 9 No. 1, pp. 41-66.

Landry, C.E., Bergstrom, J., Salazar, J. and Turner, D. (2021), "How has the COVID-19 pandemic affected outdoor recreation in the US? A revealed preference approach", Applied Economic Perspectives and Policy, Vol. 43 No. 1, pp. $443-457$.

Le Corre, N., Saint-Pierre, A., Hughes, M., Peuziat, I., Cosquer, A., Michot, T. and Bernard, N. (2021), "Outdoor recreation in French Coastal and Marine Protected Areas. Exploring recreation experience preference as a way for building conservation support", Journal of Outdoor Recreation and Tourism, Vol. 33, p. 100332.

Lee, E.S., Park, T.Y. and Koo, B. (2015), "Identifying organizational identification as a basis for attitudes and behaviors: a meta-analytic review", Psychological Bulletin, Vol. 141 No. 5, p. 1049.

Lin, Y.H. and Lee, T.H. (2020), "How do recreation experiences affect visitors' environmentally responsible behavior? Evidence from recreationists visiting ancient trails in Taiwan", Journal of Sustainable Tourism, Vol. 28 No. 5, pp. 705-726.

Liu, J., Zhao, Y. and Jang, S. (2021), 'Understanding beach tourists' environmentally responsible behaviors: an extended value-attitude-behavior model", Journal of Travel and Tourism Marketing, Vol. 38 No. 7, pp. 696-709. 
Loewenstein, G.F., Weber, E.U., Hsee, C.K. and Welch, N. (2001), "Risk as feelings", Psychological Bulletin, Vol. 127 No. 2, p. 267.

MacKenzie, S.B. and Lutz, R.J. (1989), "An empirical examination of the structural antecedents of attitude toward the ad in an advertising pretesting context", Journal of Marketing, Vol. 53 No. 2, pp. 48-65.

Marasinghe, S., Perera, P., Simpson, G.D. and Newsome, D. (2021), "Nature-based tourism development in coastal wetlands of Sri Lanka: an importance-performance analysis at Maduganga Mangrove estuary", Journal of Outdoor Recreation and Tourism, Vol. 33, p. 100345.

Mardia, K.V. (1971), "The effect of nonnormality on some multivariate tests and robustness to nonnormality in the linear model”, Biometrika, Vol. 58 No. 1, pp. 105-121.

Margaryan, L. and Fredman, P. (2017), "Bridging outdoor recreation and nature-based tourism in a commercial context: insights from the Swedish service providers", Journal of Outdoor Recreation and Tourism, Vol. 17, pp. 84-92.

Matiza, T. (2020), "Post-COVID-19 crisis travel behaviour: towards mitigating the effects of perceived risk", Journal of Tourism Futures, Vol. ahead-of-print No. ahead-of-print, doi: 10.1108/JTF-04-2020-0063.

Mckenzie-Mohr, D. (2000), "New ways to promote proenvironmental behavior: promoting sustainable behavior: an introduction to community-based social marketing", Journal of Social Issues, Vol. 56 No. 3, pp. 543-554.

Melly, D. and Hanrahan, J. (2020), "Tourist biosecurity awareness and risk mitigation for outdoor recreation: management implications for Ireland”, Journal of Outdoor Recreation and Tourism, Vol. 31, p. 100313.

Mkono, M. (2020), "Eco-anxiety and the flight shaming movement: implications for tourism", Journal of Tourism Futures, Vol. 6 No. 3, pp. 226-235.

Nezakati, H., Amidi, A., Jusoh, Y.Y., Moghadas, S., Aziz, Y.A. and Sohrabinezhadtalemi, R. (2015), "Review of social media potential on knowledge sharing and collaboration in tourism industry", Procedia-social and Behavioral Sciences, Vol. 172, pp. 120-125.

Nordh, H., Vistad, O.I., Skår, M., Wold, L.C. and Bærum, K.M. (2017), "Walking as urban outdoor recreation: public health for everyone", Journal of Outdoor Recreation and Tourism, Vol. 20, pp. 60-66.

Nunnally, J.C. and Bernstein, I.H. (1994), Psychometric Theory, 3rd ed., McGraw-Hill, New York.

Oliveira, T., Araujo, B. and Tam, C. (2020), "Why do people share their travel experiences on social media?", Tourism Management, Vol. 78, p. 104041.

Osbaldiston, R. and Sheldon, K.M. (2003), "Promoting internalized motivation for environmentally responsible behavior: a prospective study of environmental goals", Journal of Environmental Psychology, Vol. 23 No. 4, pp. 349-357.

Oskamp, S. (2002), "Environmentally responsible behavior: teaching and promoting it effectively", Analyses of Social Issues and Public Policy, Vol. 2 No. 1, pp. 173-182.

Peeri, N.C., Shrestha, N., Rahman, M.S., Zaki, R., Tan, Z., Bibi, S. and Haque, U. (2020), "The SARS, MERS and novel coronavirus (COVID-19) epidemics, the newest and biggest global health threats: what lessons have we learned?", International Journal of Epidemiology, Vol. 49 No. 3, pp. 717-726.

Perkins, H.E. and Brown, P.R. (2012), "Environmental values and the so-called true ecotourist", Journal of Travel Research, Vol. 51 No. 6, pp. 793-803.

Pham, H.S.T. and Chi, T.K.N. (2020), "Ecotourism intention: the roles of environmental concern, time perspective and destination image", Tourism Review, Vol. 76 No. 5, pp. 1141-1153.

Podsakoff, P.M., MacKenzie, S.B., Podsakoff, N.P. and Lee, J.Y. (2003), "The mismeasure of man (agement) and its implications for leadership research", The Leadership Quarterly, Vol. 14 No. 6, pp. 615-656.

Rice, W.L., Taff, B.D., Miller, Z.D., Newman, P., Zipp, K.Y., Pan, B., ... and D’Antonio, A. (2020), "Connecting motivations to outcomes: a study of park visitors' outcome attainment", Journal of Outdoor Recreation and Tourism, Vol. 29, p. 100272.

Rosenstock, I.M. (1974), "Historical origins of the health belief model", Health Education Monographs, Vol. 2 No. 4, pp. 328-335.

Rustam, A., Wang, Y. and Zameer, H. (2020), "Environmental awareness, firm sustainability exposure and green consumption behaviors", Journal of Cleaner Production, Vol. 268, p. 122016. 
Schiffman, L.G. and Kanuk, L.L. (1978), Consumer Behavior, Prentice-Hall, Englewood Cliffs, NJ.

Severo, E.A., de Guimarães, J.C.F., Dorion, E.C.H. and Nodari, C.H. (2015), "Cleaner production, environmental sustainability and organizational performance: an empirical study in the Brazilian MetalMechanic industry", Journal of Cleaner Production, Vol. 96, pp. 118-125.

Severo, E.A., De Guimarães, J.C.F. and Dellarmelin, M.L. (2021), "Impact of the COVID-19 pandemic on environmental awareness, sustainable consumption and social responsibility: evidence from generations in Brazil and Portugal", Journal of Cleaner Production, Vol. 286, p. 124947.

Shi, F., Weaver, D., Zhao, Y., Huang, M.F., Tang, C. and Liu, Y. (2019), "Toward an ecological civilization: Mass comprehensive ecotourism indications among domestic visitors to a Chinese wetland protected area", Tourism Management, Vol. 70, pp. 59-68.

Sisneros-Kidd, A.M., D’Antonio, A., Monz, C. and Mitrovich, M. (2021), "Improving understanding and management of the complex relationship between visitor motivations and spatial behaviors in parks and protected areas", Journal of Environmental Management, Vol. 280, p. 111841.

Sjöberg, L. (1998), "Worry and risk perception”, Risk Analysis, Vol. 18 No. 1, pp. 85-93.

Spennemann, D.H. and Whitsed, R. (2021), "The impact of COVID-19 on the Australian outdoor recreation industry from the perspective of practitioners", Journal of Outdoor Recreation and Tourism, Vol. 67, pp. 110, 100445.

Stern, P. (2000), "Toward a coherent theory of environmentally significant behavior", Journal of Social Issues, Vol. 56 No. 3, pp. 407-424.

Straub, D., Boudreau, M.C. and Gefen, D. (2004), "Validation guidelines for IS positivist research", Communications of the Association for Information Systems, Vol. 13 No. 1, p. 24.

Tabachnick, B.G. and Fidell, L.S. (2013), Using Multivariate Statistics, International edition, Pearson.

Tao, C.H., Eagles, P.F. and Smith, S.L. (2004), "Profiling Taiwanese ecotourists using a self-definition approach", Journal of Sustainable Tourism, Vol. 12 No. 2, pp. 149-168.

Tkaczynski, A., Rundle-Thiele, S. and Truong, V.D. (2020), "Influencing tourists' pro-environmental behaviours: a social marketing application", Tourism Management Perspectives, Vol. 36, p. 100740.

Truong, V.D. and Hall, C.M. (2017), "Corporate social marketing in tourism: to sleep or not to sleep with the enemy?", Journal of Sustainable Tourism, Vol. 25 No. 7, pp. 884-902.

Tuoitrenews (2020), "Current and proposed UNESCO world heritage sites in Vietnam", available at: https:// tuoitrenews.vn/news/city-diary/20190915/current-and-proposed-unesco-world-heritage-sites-in-vietnam/ 51283.html (accessed 03 February 2020).

Tweneboah-Koduah, E.Y., Mann, V.E. and Adams, M. (2020), "Using motivation, opportunity, and ability model in social marketing to predict 'galamsey' behavior in Ghana”, Social Marketing Quarterly, Vol. 26 No. 1, pp. 28-46.

Wearing, S. and McDonald, M. (2002), "The development of community-based tourism: Re-thinking the relationship between tour operators and development agents as intermediaries in rural and isolated area communities", Journal of Sustainable Tourism, Vol. 10 No. 3, pp. 191-206.

Wen, J., Kozak, M., Yang, S. and Liu, F. (2020), "COVID-19: potential effects on Chinese citizens' lifestyle and travel", Tourism Review, Vol. 76 No. 1, pp. 74-87.

Yllmaz, Y. and Anasori, E. (2021), "Environmentally responsible behavior of residents: impact of mindfulness, enjoyment of nature and sustainable attitude", Journal of Hospitality and Tourism Insights, Vol. 5 No. 1, pp. $1-14$.

Zhang, K.J. and Lei, J.S. (2012), "The research on the entrepreneurial motivation of university students based on the achievement goal theory", Studies in Science of Science, Vol. 8.

\section{Corresponding author}

Nguyen Thi Khanh Chi can be contacted at: chintk@ftu.edu.vn

For instructions on how to order reprints of this article, please visit our website: www.emeraldgrouppublishing.com/licensing/reprints.htm

Or contact us for further details: permissions@emeraldinsight.com

PAGE $16 \mid$ JOURNAL OF TOURISM FUTURES $\mid$ VOL. $\mathbf{m}$ NO. $\mathbf{m}$ 